\title{
UPOTREBA DELA INTELEKTUALNE SVOJINE U CYBER PROSTORU
}

\author{
Žaklina Spalević1, \\ Miloš llić2*, \\ Petar Spalević \\ 1 Univerzitet Singidunum, \\ Beograd, Srbija \\ ${ }^{2}$ Fakultet tehničkih nauka, \\ Univerzitet u Prištini, \\ Kosovska Mitrovica, Srbija
}

\begin{abstract}
Rezime:
Brzi razvoj i upotreba informaciono komunikacionih tehnologija poslednjih godina doveli su do velikih promena u svakodnevnom životu i radu ljudi. Ove promene pre svega se ogledaju u količini informacija dostupnih u digitalnom obliku. Cyber prostor koji je nastao kao posledica digitalizacije sadržaja kao i stalne upotrebe informaciono komunikacionih tehnologija i Interneta trenutno predstavlja najveći izvor informacija. Različiti oblici digitalnih informacija u cyber prostoru su dostupni korisnicima istog. Pored sadržaja koji su javno dostupni i mogu se koristiti bez ikakvih ograničenja u isto vreme veliki procenat digitalnih informacija je zaštićen pravom intelektualne svojine i autorskim i srodnim pravima. Uprkos primenjenoj zaštiti autorskih dela u praksi se javlja veliki broj zloupotreba. Cilj ovog rada je analiza trenutnog stanja primene mehanizama zaštite intelektualne svojine u cyber prostoru sa posebnim osvrtom na primenu ovih mehanizama u Republici Srbiji. Mehanizmi zaštite intelektualne svojine sagledani su kroz domen primene informaciono komunikacionih tehnologija, pravnih aspekata i registrovanih zloupotreba.
\end{abstract}

Ključne reči:

Copyright, open source, licence otvorenog tipa, cyber prostor, piratstvo.

\section{UVOD}

Intelektualna svojina se može posmatrati kao vlasništvo nad dobrima nematerijalnog karaktera. S tim u vezi dobra koja spadaju u intelektualnu svojinu moraju biti proizvod intelekta osobe kojoj dobro pripada. Takođe intelektualna dobra $\mathrm{u}$ isto vreme mogu predstavljati i proizvod kreativnosti i inovativnosti osobe kojoj pripadaju. Posmatrano iz ugla nastanka intelektualna svojina podstiče stvaralački stranu čoveka, i u isto vreme utiče na pomeranje granica nauke i tehnike. Pored naučnih i tehničkih dobara koja su proizvod intelektualnog stvaralaštva pomenuta intelektualna dobra koja nastaju kao proizvod kreativne ljudske strane utiču na povećanje i obogaćivanje sveta književnim i umetničkim delima. Ukoliko se intelektualna svojina posmatra iz domena autora dela ili njegovog stvaraoca može se reći da ona predstavlja specifična prava samog autora, pronalazača ili nosioca prava intelektualne svojine. Ključna činjenica koju je bitno istaći jeste da intelektualna svojina ne predstavlja materijalno vlasništvo, već skup prava i ovlašćenja dodeljenih autoru ili stvaraocu dela.
Odgovorno lice:

Miloš Ilić

e-pošta:

milos.ilic@pr.ac.rs 
Ovo praktično znači da su prava i ovlašćenja obezbeđena autoru i stvaraocu dobra. Pravni okviri intelektualne svojine bazirani su na sporazumima i ugovorima koji su nastali kao produkt rada radnih grupa na međunarodnom nivou, kao i na pravnim normama definisanim u nacionalnom zakonodavstvu svake od zemalja. Problem koji se javlja sa nematerijalnim dobrima koja su zaštićena pravom intelektualne svojine jeste način upotrebe i pravilna zaštita istih u cyber prostoru. Veliki broj korisnika svesno ili nesvesno zanemaruje činjenicu da su dela kojima pristupaju zaštićena autorskim pravom, i da se ne mogu slobodno koristiti. Dostupnost autorskih dela u digitalnom obliku kao što su naučni radovi, književna dela, audio i video materijali, različite vrste softvera u mnogome je otežala primenu koncepata autorskih prava. Upravo iz ovog razloga dobro poznati tradicionalni koncept autorskih prava morao se prilagoditi digitalizaciji sadržaja koje je potrebno zaštiti. Kako bi se zaštitila autorska dela u digitalnom obliku kreirani su novi koncepti kao što su: licence otvorenog sadržaja, open source softver, copy left licence, licence kreativne zajednice (Creative Commons Licenses - CCL) itd.

Rad je organizovan na sledeći način. Drugi deo ovog daje pregled pravnih normi i principa intelektualne svojine i autorskog prava koji se primenjuju prilikom zaštite intelektualnih dobara. Treći deo rada daje opis licenci otvorenog tipa kao i načine njihovih primeni. U četvrtom delu dat je opis različitih mehanizama zloupotrebe dela zaštićenih autorskim pravom. Peti deo sumira registrovana i procesuirana krivična dela protiv autorskog prava u Republici Srbiji. Glavni zaključci i reference dati su u poslednja dva dela ovog rada.

\section{PRINCIPI INTELEKTUALNE SVOJINE I AUTORSKOG PRAVA}

Pravo intelektualne svojine kao svojevrsna zaštita dobara nastalih kao krajnji produkt individualnog ili grupnog stvaralaštva datiraju još od Ustava SAD-a. Prema članu 1 Ustava SAD-a kongresu je dat autoritet $\mathrm{u}$ domenu podsticanja i unapređenja nauke i korisnih veština. Na ovakav način Kongres obezbeđuje pronalazačima i piscima isključiva prava nad njihovim delima i pronalascima. Trajanje ovih prava je ograničeno, dok je sami vremenski rok unapred definisan. Zahvaljujući vrlo ranim naporima u ovoj oblasti kao i multilateralnim konvencijama koje pokrivaju ovu oblast, područje intelektualne svojine jedna je od retkih grana prava koja uživa visok stepen usaglašenosti u većini pravnih sistema.
U sklopu intelektualne svojine mogu se izdvojiti dve kategorije u koje se razvrstavaju sva dela koja je potrebno zaštiti. Ove dve kategorije su:

- Industrijska svojina. U ovu kategoriju mogu se uvrstiti patenti kao najpoznatiji oblik industrijske svojine. Pored patenata u kategoriju industrijske svojine takođe spadaju žigovi kompanija, oznake geografskog porekla, dela nastala kao rezultat industrijskog dizajna, pa čak i šeme integrisanih kola.

- Autorsko pravo i srodna prava. U ovu kategoriju ubrajaju se dela književnosti, nauke i umetnosti. Ukoliko se posmatra broj aktera na razvoju samog dela koje se štiti autorskim pravom u ovu kategoriju najčešće se svrstavaju dela koja su rezultat intelektualnog i stvaralačkog napora pojedinca.

Kao što je bio slučaj sa odredbama Ustava SAD-a vezanim za intelektualnu svojinu tako i ostale zemlje i međunarodne organizacije za svaki predmet proglašen intelektualnom svojinom bez obzira kojoj kategoriji delo pripada definišu vremensko ograničenje trajanja zaštite. Primera radi u Republici Srbiji maksimalno vreme trajanja zaštite nekog dela u vidu patenta iznosi 20 godina. $S$ druge strane maksimalno vreme zaštite žigova iznosi 10 godina uz mogućnost neograničenog obnavljanja zaštite. U praksi zaštita industrijskog vlasništva primera radi patentiranje nekog pronalaska ili proizvoda postiže se uobičajenim postupcima. Ovi postupci podrazumevaju priznavanje prava ili registrovanja konkretnog patenta. Sami proces priznavanja prava sprovode nadležna tela za određeno područje. Pomenuto područje u najvećem broju slučajeva je država na čijoj teritoriji je delo koje se želi zaštiti nastalo, što predstavlja princip teritorijalnosti. U manjem broju slučajeva može se raditi o zaštiti na području regije. Ukoliko se posmatra na ovakav način regija bi pokrivala šire područje pa bi na takav način i sama zaštita imala snažnije dejstvo. Primera radi u Republici Srbiji Zavod za intelektualnu svojinu zadužen je za sprovođenje postupka za dodeljivanje prava intelektualne svojine.

Za razliku od industrijske svojine gde su dela najčešće od naučnog ili tehničkog značaja i gde su dela nastala kao proizvod kolektivnog rada autorsko delo može biti originalna intelektualna tvorevina koja može pripadati književnom, naučnom ili umetničkom području. Da bi se delo svrstalo u autorsko mora imati individualni karakter. Ako se posmatra domen intelektualnih tvorevina iz književnog područja ovde bi se mogli svrstati romani, pesme, pripovetke, i dramska dela. Pod tvorevinama iz 
domena naučnog područja mogu se posmatrati pronalasci, patenti, i u novije vreme računarski programi i baze podataka. Na kraju u tvorevine umetničkog područja mogu se svrstati filmovi, muzička dela, koreografska dela, dela likovne umetnosti, dela arhitekture, primenjenih vrednosti, skice, fotografije, itd.

Postupak dodeljivanja autorskih prava nad nekim delom kao i prava intelektualne svojine mora biti definisan zakonskim odredbama. U Republici Srbiji odredbe kojima se uređuje autorsko pravo definisane su Zakonom o autorskim i srodnim pravima ${ }^{1}$. Prema ovom Zakonu autorsko delo definisano je kao duhovna tvorevina originalnog karaktera. Ovako kreirana duhovna tvorevina mora biti izražena u određenoj formi. Ovo praktično znači da bez obzira umetničku, naučnu ili drugu vrednost samog dela, kao i njegovu namenu, veličinu, sadržinu i način ispoljavanja delo mora ispoštovati određenu formu. Sama forma dela odnosi se i na dopuštenost javnog saopštavanja njegove sadržine.

Zakonom je takođe definisano da svaki autor raspolaže moralnim, imovinskim i ostalim pravima i to od samog trenutka nastanka autorskog dela. Pod moralnim pravima autoru se smatra pravo priznavanja autorstva nad njegovim delom, kao i pravo da njegovo ime bude jasno navedeno na svakom izdatom primerku dela. Takođe autor ima pravo da objavi svoje delo. Tačnije autor prema ovom zakonu može odrediti sami način na koji će se predmetno delo objaviti. Pod imovinskim pravima spada pravo na umnožavanje dela, pravo na sticanje ekonomske dobiti u vidu distribucije dela ili njegovog davanja u zakup, kao i pravo na izvođenje, emitovanje i javno saopštavanje. Grupa ostalih prava obuhvata pravo na pristup primerku dela, pravo sleđenja, kao i pravo zabrane izlaganja originalnog primerka ukoliko se radi o delima likovne umetnosti. U ovu grupu ubraja se i preče pravo autora koje se odnosi na izmenu primerka arhitekturnog dela.

Pored autorskog prava Zakonom je predviđeno i definisanje srodnih prava autorskom pravu. Ova prava najčešće se odnose na pravnu zaštitu autorskih dela koja obuhvataju:

- pravo interpretatora;

- pravo proizvođača fonograma;

- pravo proizvođača videograma;

- pravo proizvođača emisije;

- pravo proizvođača baze podataka;

- pravo prvog izdavača slobodnog dela i

- pravo izdavača štampanih izdanja na posebnu naknadu.

1 Zakon o autorskim i srodnim pravima, Službeni glasnik RS, br. 104/2009, 99/2011, 119/2012 I 29/2016 - odluka US.
Kao što se iz navedenog može videti u najvećem broju slučajeva zaštita srodnim pravom odnosi se na audio i video zapise, dela nastala u radiodifuziji, kao i na domen zaštite organizacionih poslovnih i finansijskih ulaganja $\mathrm{u}$ iste. Uopšteno govoreći stvaraoci dela koja su zaštićena autorskim pravom kao i njihovi naslednici i pravni sledbenici nazivaju se nosiocima autorskog prava. Sva svoja prava definisana Zakonom nosioci mogu ostvariti na dva načina: individualno ili kolektivno. Individualno ostvarivanja prava praktično znači da je konkretna osoba stvorila originalnu intelektualnu tvorevinu. U tom slučaju sami autor činom stvaranja dela ostvario je autorsko pravo, i nije u obavezi da ispunjava bilo kakve druge formalnosti kao što su registracija ili depozit rada. Ukoliko je više autora radilo na stvaranju dela, pri čemu je delo kao takvo nedeljiva celina svakom od autora pripada zajedničko autorsko pravo nad stvorenim delom. Ovako kreirano delo naziva se koautorsko delo. Sa druge strane ukoliko je delo moguće podeliti na pojedinačne delove na kojima su autori aktivno radili, a nakon toga radi njihovog zajedničkog korišćenja spojili sve delove u zajednički rad u tom slučaju svaki pojedinačni učesnik ima autorsko pravo nad onim delo rada koji je samo njegov [1]. Organizacija za kolektivno ostvarivanje autorskih prava nikada se ne osniva radi sticanja dobiti. Nosioci autorskog odnosno srodnih prava posredstvom organizacije za kolektivno ostvarivanje prava mogu da ostvaruju imovinska prava i prava na potraživanje naknade. Autori mogu da potražuju naknadu za ona svoja dobra koja su zaštićena autorskim pravom. Zakonom je definisano da ukoliko autor ostvaruje samo imovinska prava to praktično znači da će on ugovorom morati na isključiv način da ustupi sva svoja prava organizaciji. Nakon ustupanja prava organizacija u ime autora obavlja poslove zaključivanja ugovora sa korisnicima predmetnih dela o neisključivom ustupanju tih prava. Kada se radi o ostvarivanju prava na naknadu organizacija $\mathrm{u}$ ime nosioca autorskih prava a na njegov zahtev vrši naplatu od korisnika dela. U ovakvim slučajevima organizacija zadržava pravo da vrši kontrolu iskorišćavanja predmeta pod zaštitom autorskim pravom. Shodno Zakonu u slučaju spora organizacija ima pravo i dužna je da pred sudom kao ovlašćeno lice štiti interese i prava nosioca autorskog prava [2].

Ovako definisani nosioci poseduju određena prava i privilegije koja se odnose na konkretno autorsko delo. Prava i privilegije omogućavaju nosiocu da zabraniti ili odobriti reprodukovanje u svim oblicima, uključujući štampanje i zvučne zapise. Takođe nosilac ovim pravima može odobriti javno izvođenje i saopštavanje dela. 
U slučaju zahteva za prevođenjem dela na druge strane jezike, kao i zahteva za eventualnom adaptacijom na nosiocu autorskog prava je da li će ili neće iste odobriti.

Pored autorskog prava Zakonom je definisano i javno vlasništvo nad nekim delom. Gotovo se može reći da je uvođenje javnog vlasništva podjednako važno kao i postojanje autorskih prava. Razlozi za uvođenje javnog vlasništva različiti su i kreću se od domena obrazovnog karaktera preko demokratskog i ekonomskog pa sve do uspostavljanja slobodne konkurencije. Uloga javnog vlasništva ogleda se u stvaranju pozitivne atmosfere slobodnog stvaralaštva, kulturološke različitosti, inovativnosti pojedinaca i gupe, kao i razvoju nauke i kulture. Posebno je značajan uticaj javnog domena u kulturi i nauci. U ovim oblastima javni domen se ogleda u stvaranju kulturnih i naučnih dobara koja će biti dostupna svima. $\mathrm{Na}$ ovakav način uvođenjem javnog domena dela su zaštićena od privatizacije i prisvajanja. Još bitnija osobina javnog vlasništva jeste uspostavljanje balansa između svima dostupnih dela i isključivosti koju nosi intelektualna svojina. Prema Bernskoj konvenciji iz 1886. godine javnom vlasništvu pripadaju dela kojima je prestala autorsko pravna zaštita. Ovo praktično znači da intelektualna dela i kreacije nakon prestanka prava intelektualne svojine prelaze u javno vlasništvo intelektualne svojine. U skladu sa Bernskom konvencijom određena dela se mogu podrazumevano klasifikovati u javno vlasništvo. Član 2 stav 4 ove konvencije definiše da zvanični tekstovi zakonodavne, administrativne i pravne prirode, kao i zvanični prevodi ovakvih tekstova ne mogu se zaštiti autorskim pravom. Pored zvaničnih dokumenata članom 2 stav 8 Bernske konvencije definisano je da u domen javnog vlasništva obavezno spadaju i dnevne vesti i informacije. Veliki broj zemalja prati konvenciju onako kako je definisana u cilju ograničavanja zaštite autorskim pravom, dok pojedine zemlje vrše i dopunu svojim nacionalnim zakonima. U zemljama poput Alžira, Kine, Francuske, Italije, Koreje pod javnim vlasništvom se smatraju u najmanju ruku zakoni i pod zakonski akti, kao i sudske odluke. Pojedine države u nekim slučajevima vrše proširenje domena podrazumevanog javnog vlasništva na dela proizvedena ili subvencionisana od strane države ili drugih javnih ustanova. $U$ grupu ovakvih država ubrajaju se Brazil, Malezija, SAD. Primera radi Nemačka odobrava i slobodu korišćenja i izmene takvih dokumenata. Sudska praksa ponekad isključuje dela koja imaju normativnu vrednosti, kao što su bankovne novčanice, zvanični ispiti za određene profesije, kao i mišljenja data od strane nekog sudije. Da postoje i države koje ne primenjuju principe ove konvencije svedoče i primeri država koje priznaju Crown Copyright kao što su Velika Britanija i Australija. Zemlje koje praktikuju ovakvu zaštitu sklanjaju službena dela iz javnog domena i daju im zaštitu autorskim pravom, dok je nosilac zaštite država (u slučaju Australije) ili kraljica (u slučaju Velike Britanije) [13]. Ako posmatramo dnevne vesti kao jedan od oblika javnog vlasništva Kina, Kosta Rika, Italija, Koreja bile bi neke od zemalja koje ovo pravilo eksplicitno pružaju. Postoje i primeri da države nacionalnim zakonima određene kategorije dela prebacuju iz autorskim pravom zaštićene kategorije u domen javnog vlasništva. Članom 11 Zakona o autorskim pravima (Copyright Act) Čile je definisao da dela koja su dobijena eksproprijacijom od strane države postaju javno vlasništvo. Ovakva praksa uvedena je početkom 70-tih godina kada je vlada socijalista na ovakav način održavala duh vremena kada su eksproprijacije za javni interes bile politička strategija. Članom 66 Zakona o autorskim pravima Kosta Rike kao i članom 45 istog zakona Brazila definisano je da dela zaštićena autorskim pravom postaju javno vlasništvo nakon smrti nosioca autorskog prava ukoliko nosilac prava nema zakonske naslednike.

\section{LICENCE OTVORENOG SADRŽAJA}

Velika količina informacija koja se razmenjuje putem internet servisa, kao i različitost publikovanog sadržaja stvorili su potrebu definisanja opštih licenci. Ovim licencama definisan je način i mera u kojoj se može koristiti određeno autorsko delo. Ovo praktično znači da će privilegije korišćenja autorskog dela zavisiti od vrste licence koja se primenjuje nad njim. Pravilima definisanim u okviru ovih licenci autor samostalno donosi odluku da li će ili neće dozvoliti komercijalnu ili nekomercijalnu upotrebu svog dela. Nekomercijalno korišćenje autorskog dela u praksi ne mora obavezno značiti i neostvarivanje ekonomske dobiti za autora dela. Praktično autor u ovom slučaju ipak može ostvariti ekonomsku dobit ukoliko sa izdavačkom kućom sklopi ugovor. Na osnovu ovako definisanog ugovora autoru će sama izdavačka kuća isplatiti određenu ekonomsku nadoknadu. U procesu licenciranja licencama otvorenog sadržaja autori moraju poštovati proceduru licenciranja kako bi se za predmetno delo moglo smatrati da je zaista i licencirano. Kako se za upotrebu dela licenciranog licencom otvorenog sadržaja ne zahteva finansijska nadoknada svaka ovakva licenca sadrži klauzulu na osnovu koje licenca ne daje nikakvu garanciju autoru dela. Zavisno od karakteristika privilegija koje nude licence 
otvorenog sadržaja mogu se podeliti na licence opšteg tipa ili licence specijalne namene. Takođe prema prirodi ove licence se mogu podeliti na licence sa malim ograničenjima i licence kojima su jasno definisana ograničenja korišćenja dela. Primera radi Licence kreativne zajednice su licence kojima se jasno definišu ograničenja u slobodi korišćenja autorskog dela [3].

U domen licenci specijalne namene kojima se definišu posebna prava i privilegije korišćenja spadaju licence za softverska rešenja. S tim u vezi može se reći da se kod distribucije softvera definišu različite licence u zavisnosti od privilegija dodeljenih korisniku. Što se tiče softvera otvorenog izvornog koda (engl. open source software) on predstavlja vrstu softverskih licenci kod kojih je programski kod dostupan svakome ko želi da ga unapredi ili razvije. U sklopu ovih licenci definišu se različite druge podele, ali suština besplatnog softvera ostaje ista. Njihove glavne razlike su vezane za upotrebu izvornog koda u drugim projektima kao i upotrebi softvera proizašlog iz tih novih projekata. Primeri softvera otvorenog izvornog koda: Linux, OpenOffice, apache web server. Primeri ovako koncipiranih licenci koje su danas u upotrebi dati su u nastavku:

- GPL (General Public License). Ovaj tip licence daje korisniku veoma široka prava koja se ogledaju u mogućnosti redistrubucije i obrnutog inženjeringa. Ovo praktično znači da korisnik može vršiti izmene na softveru. Iako se korisniku omogućava vršenje izmena nad izvornim kodom softvera on ipak mora ispuniti određene uslove propisane ovim tipom licenci. Jedan od osnovnih uslova je i obaveza objavljivanja svih izmena izvornog koda.

- LGPL (Lesser General Public License), licenca se uglavnom primenjuje na softverske biblioteke. Ovo praktično znači da korisnik može da distribuira i modifikuje softver tako da sve što je povezano sa bibliotekom potpada pod samu licencu i može se tako distribuirati, dok sama kreirana aplikacija koja koristi biblioteku ne može biti pod ovom licencom [4].

- BSD (Berkeley Source Distribution). licenca garantuje krajnjem korisniku potpunu autonomnost nad softverom. Na ovakav način korisniku se omogućava da predmetni softver i njegov izvorni kod iskoristi kao deo softvera zatvorenog koda objavljenog pod vlasničkom licencom.

Jedan od možda najboljih primera primene licenci otvorenog sadržaja jeste GNU pokret ili GNU zajednica. Ova zajednica predstavlja jednu od prvih praktičnih i uspešnih inicijativa koje omogućavaju korisnicima softvera da slobodno koriste prednosti koje nudi korišćenje informaciono komunikacionih tehnologija. Sami pokret počeo je sa aktivnostima 1984. godine. Njegov cilj bio je stvaranje operativnog sistem otvorenog koda pod nazivom UNIX. Za GNU GPL licencu slobodno se može reći da predstavlja jednu od široko poznatih licenci kada je softverska industrija u pitanju. Samom licencom definisana je sloboda korišćenja softvera, njegovog kopiranja, izmene kao i distribucije svih verzija softvera nastalih na bazi osnovne verzije. Praktično distribucija slobodnog softvera mora da se vrši pod istovetnim uslovima pod kojima je prvobitno sami softver korisnik dobio. $\mathrm{Na}$ ovakav način GPL daje slobodu i korisniku i softveru. Upotreba licenci kreativne zajednica prvobitno je bila orijentisana ka fizičkim licima (autorima kreativnih dela), međutim sa sve većim problemima sa kojima se kreativna zajednica susreće po pitanju zaštite autorskih prava sve je veći broj korisnika ovih licenci iz reda pravnih lica i državnih organa. Sve ovo svedoči o značaju ovakvog kreiranja i korišćenja licenci.

\section{KRŠENJE AUTORSKOG PRAVA U CYBER PROSTORU}

Popularizovanju upotrebe interneta i njegovom brzom širenju u mnogome je doprinelo otvaranje mreže za javni pristup, jednostavnost publikovanja sadržaja, lako pronalaženje istog kao i pristup velikoj količini informacija različitog sadržaja na jednom mestu. Velika količina informacija dovela je do teškog razlikovanja sadržaja koji je zaštićen autorskim pravima od onog koji nije. Ukoliko se uporedi sa štampanim delima kao i delima na nosiocima slike i zvuka kod kojih je jasno naznačeno ko je nosioc autorskog prava i da li je delo zaštićeno autorskim pravom, u slučaju cyber prostora korisnici nisu uvek u mogućnosti da ustanove legalne načine preuzimanja, izmene i kasnije reprodukcije određenog dela. Međutim korisnici ovakvih sadržaja uvek bi trebalo da imaju na umu da većina sadržaja podleže autorskim pravima.

Uopšteno govoreći mogu se istaći dva najznačajnija oblika i predmeta potencijalnih kršenja intelektualne svojine, a to su softver i multimedijalni sadržaji u digitalnom obliku. Softver i multimedijalni sadržaji kao takvi sa jedne strane najčešće podležu zaštiti autorskim pravom i nude se korisnicima interneta uz određenu nadoknadu. U ovu grupu sadržaja najčešće spadaju audio i video sadržaji, igrani i dokumentarni filmovi, komercijalni i softveri za kućnu i ličnu upotrebu, kao 
i multimedijalni tutorijali kreirani od strane pojedinca ili organizacije [5]. U cilju razmene i kopiranja fajlova bez poštovanja autorskih prava koriste se i servisi koji omogućavaju računarima direktno međusobno povezivanje bez posredovanja centralnog servera. Jedan od prvih servisa za razmenu muzičkih fajlova pojavio je 2000. godine. Ovaj servis nosio je naziv Napster i omogućio je milionima korisnika razmenu uglavnom autorskim pravima zaštićene muzičke fajlove. Posle niza sudskih sporova servis je ugašen. Gašenje ovog servisa nije obeshrabrilo korisnike ovakvih servisa u pokušajima kreiranja i upotrebe novih. Novi servisi koji su i danas u upotrebi u svom radu primenjuju drugačiji protokol koji u velikoj meri onemogućava krivično gonjenje lica. Ovaj protokol nazvan je BitTorrent. Sama činjenica da lice koje učestvuje u razmeni fajlove ne može biti procesuirano dovela je do masovne upotrebe ovih servisa. Ovi servisi poslednjih godina nisu ograničeni samo na deljenje muzičkih fajlova. Putem ovi servisa korisnici mogu preuzeti gotovo sve digitalne sadržaje od muzike preko video sadržaja sve do različitih vrsta softvera. Da torent fajl nije nelegalan dokazuje i presuda suda države Ajova iz 2014. godine, kojom je ovaj sud masovnu tužbu protiv BitTorrent korisnika odbio kao neosnovanu. U prilog odbijanju išla je činjenica da nije bilo moguće dokazati vezu između torent fajla i internet pirata [6].

Sa druge strane veliki broj sudskih presuda protiv različitih servisa za deljenje torent fajlova svedoči o tome koliko je borba protiv ovakvog kršenja autorskih prava postojana. Jedan od primera je sudski spor koji se vodio pred sudom u Finskoj. Naime nakon upada policije na Bit Torent sajt pod nazivom Finreactor uhapšeno je jedanaest osoba. Za načinjenu štetu zbog distribucije autorskim pravom zaštićenog digitalnog materijala naloženo im je da plate pola miliona evra odštete i 200.000 evra na ime sudskih troškova. Ceo proces je nakon niza žalbi optuženih stigao do Vrhovnog suda Finske koji je još jednom potvrdio prvostepenu presudu [7]. Šest administratora EliteTorrents.org sajta nakon preuzimanja kontrole nad sajtom od strane Federalnog istražnog biroa Sjedinjenih Američkih Država priznalo je krivicu za učešće u zaveri u kojoj su izvršena krivična dela kršenja autorskih prava i objavljivanja radova pre njihovog komercijalnog izdavanja. Njima su nakon suđenja izrečene kazne zatvora, kućnog pritvora kao i novčane kazne. Izrečene zatvorske kazne zasnovane su na krivičnom zakonu [8]. Hapšenje Artem Vaulina vlasnika KickAssTorents izvedeno je u koordinisanoj akciji IRS-a i Homeland Security-a . U postupku pribavljanja činjenica koje su dovele do hapšenja učestvovali su takođe
Facebook i Apple putem čijih servisa je ustanovljena IP adresa računara sa koga je Artem pristupao. Ista IP adresa je korišćena za kupovinu na iTunesu kao i za pristupanje KickAssTorents Facebook stranici. Takođe je bila povezana sa Bitcoin računom na koji su pokrovitelji uplaćivali donacije u cilju podrške KickAss torentu [9]. Artem je optužen za kršenje autorskih prava i pranje novca. Na računu otvorenom u litvanskoj banci u cilju čuvanja novca prikupljenog od nelegalnih transkacije u toku perioda od sedam meseci istražitelji su evidentirali nešto više od 31 milion dolara. Procenjuje se da je sami torent servis tokom svog postojanja distribuirao različite digitalne sadržaje u vrednosti od preko milijardu dolara. Direktno preuzimanje fajlova zaštićenih autorskim pravom još jedan je od vidova kršenja istih. Neki od primera web sajtova za direktno preuzimanje su Mega.co.nz, FileShare.link, itd. U optužnici protiv vlasnika Megauploada Kim Dotcom-a kao i tri direktora uhapšenih na Novom Zelandu 2012. godine navodi se da su kršenjem autorskih prava oštetili nosioce autorskih prava različitih filmova, serija i drugih sadržaja za više od 500 miliona dolara. Oni su uhapšeni po optužnici zvaničnika SAD-a [10]. U optužnici se navodi da je Dotkom, koji je inače rodom iz Nemačke sa trenutnim mestom boravka u Hongkongu i Novom Zelandu zaradio u 2010. godini 42 miliona dolara. Zanimljivo je da pored dva mesta boravka Dotkom ima i dvojno državljanstvom Finske i Nemačke. Procena stručnjaka je da su na bazi pretplate za premium naloge ovaj servis a samim tim i njegovi vlasnici zaradili nešto više od 175 miliona dolara [11].

Jedan od trendova kršenja autorskih prava koji se pojavio sa razvojem veće brzine interneta jeste onlajn gledanje sadržaja (streaming). Ovakav princip u upotrebi je kod gledanja digitalnog sadržaja u vidu različitih video zapisa, serija, filmova, emisija, itd. Takođe u ovu grupu sajtova spadaju i sajtovi koji omogućavaju praćenje sporskih ili drugih kanala za koje je potrebno platiti mesečnu pretplatu. Praktično sajtovi koji pružaju ovakve usluge obično su registrovani u zemljama u kojima zaštita autorskih prava nije preterano razvijena pa se kršenje intelektualne svojine toleriše. Oko kršenja autorskih prava gledanjem digitalnog sadržaja pomoću streaming-a podeljena su mišljenja sudske prakse. Sud u Kelnu ustanovio je na bazi praćenja IP adrese da je vlasnik iste pristupao delima zaštićenim autorskim pravom, pa je isti procesuiran. Specifičnost ovog slučaja ogleda se u tome da se nije radilo o konkretnom preuzimanju sadržaja već streaming-u. Advokatska kancelarija koja je i pokrenula ovaj spor protiv velikog broj korisnika (oko 60000) agrumentovala je svoj postupak 
time da prilikom pozivanja video stream-ova dolazi do keširanja digitalnog sadržaja. Ovako keširan digitalni sadržaj kasnije je moguće kopirati ili snimiti na lokalnu memoriju računara [14]. Naime u ovim sporovima ostalo je sporno da li je advokatska kancelarija imala pravo da na bilo koji način vrši praćenje korisnika i snimanje IP adresa korisnika koji su posećivali konkretan portal. Naime sud u Hamburgu je doneo odluku da su prava privatnosti korisnika bila narušena ovakvim potezom advokatske kancelarije. U objašnjenju odluke dato je da je celokupan proces i narušavanje prava privatnosti protiv korisnika ovog streaming kanala advokatska kancelarija vodila zbog sticanja finansijske dobiti. Uvođenje ovakve odluke u sudsku praksu predstavlja pobedu korisnika streaming portala.

\section{KRIVIČNA DELA PROTIV AUTORSKOG PRAVA U REPUBLICI SRBIJI}

Definisanjem krivičnih dela vrši se upotpunjavanje zaštite prava intelektualne svojine u okviru pravnog sistema jedne zemlje. Procesuiranje dela usmerenih ka oštećenju ili krađi intelektualne svojine u Republici Srbiji spada u domen rada Posebnog tužilaštva za borbu protiv visokotehnološkog kriminaliteta. Ovo tužilaštvo obavlja poslove procesuiranja krivičnih dela određenih Krivičnim zakonikom, a koja su usmerena protiv bezbednosti računarskih podataka. Pored ovako definisanih krivičnih dela u delatnost tužilaštva spadaju i sva ona dela kod kojih se kao objekat ili sredstvo izvršenja krivičnih dela javljaju računari, računarske mreže kao i računarski sistemi. Primera radi u ovakva dela mogu se uvrstiti dela protiv intelektualne svojine, dela protiv imovine, privrede pa čak i saobraćaja. Takođe rad tužilaštva je zasnovan na procesuiranju dela u kojima se vrši povreda autorskog prava i to ukoliko se radi o pirateriji u komercijalne svrhe pri čemu broj umnoženih primeraka dela prelazi 2000, ili se pak istragom ustanovi da je autoru naneta materijalna šteta u iznosu preko milion dinara. Ukoliko su računari i računarske mreže korišćeni za potrebe izvršenja krivičnih dela protiv slobode i prava čoveka, kao i u cilju narušavanja polnih sloboda, javnog reda i mira kao i ustavnog uređenja i bezbednosti pomenuto tužilaštvo u obavezi je da procesuira i ovakva dela ${ }^{2}$. Procesuiranje lica okrivljenih za ugrožavanje autorskih i srodnih prava obuhvaćenih ovim zakonom deo je sudske prakse u Republici Srbiji duži niz godina. Primera radi u 2012. godini za krivična dela protiv

2 Krivični zakonik, “Sl. glasnik RS”, br. 85/2005, 88/2005 - ispr., $107 / 2005$ - ispr., 72/2009, 111/2009, 121/2012, 104/2013, $108 / 2014$ i $94 / 2016$. intelektualne svojine prijavljeno je 219 lica. Od ukupnog broja prijavljenih slučajeva za krivično delo neovlašćeno iskorišćavanje autorskog dela ili predmeta srodnog prava iz člana. 199. KZ prijavljeno je 24 lica³. Tokom 2013. godine zbog krivičnog dela neovlašćeno iskorišćavanje autorskog dela ili predmeta srodnog prava iz člana 199. KZ podneta krivična prijava protiv 19 lica. Tokom 2014. i 2015. godine zbog krivičnog dela neovlašćeno iskorišćavanje autorskog dela ili predmeta srodnog prava iz člana 199. KZ protiv 12 odnosno 10 lica podnete su krivične prijave. $U$ toku 2016. godine zbog istog krivičnog dela podnete su krivične prijave protiv 4 lica ${ }^{4}$. Manji broj podnetih krivičnih prijava može se sagledati sa različitih aspekta. Jedan od aspekata može biti da je broj ovakvih dela manji pa je samim tim i broj prijava manji, dok drugi aspekt može biti pokazatelj slabe angažovanosti državnih organa na rešavanju ovog problema. Jedan od primera iz sudske prakse je i presuda Okružnog suda u Beogradu K1.vtk.br.19/08 od 10. 10. 2008. god. Ovom presudom Ž. J. (36) i S. M. (35) su proglašeni krivim zbog internet piraterije. Tokom istražnog postupka njima se stavljalo na teret da su tokom tri godine na teritoriji opštine Kraljevo putem bežične veze neovlašćeno prodavali raznovrsna autorska dela. Tokom 2005. godine čak su osnovali i firmu „EXCALIBUR COM D. O. O" putem koje su primali novčane uplate na ime usluga koje su nudili. Korisnicima je nakon izvršene uplate i dostavljanja dokaza o uplati bilo omogućeno preuzimanje primeraka različitih autorskih dela. Ovom presudom okrivljeni su osuđeni na uslovnu kaznu zatvora u trajanju od šest meseci. Istom presudom rok za proveravanje iznosio je dve godine.

Drugi primer istog krivičnog dela predstavlja presuda Okružnog suda u Beogradu K1.vtk.br.44/08 od 28. 11. 2008. godine kojom je za krivično delo piraterije oglašen krivim M.S. (30) iz Beograda. M. S je takođe tokom perioda od tri godine (01.01.2005-03.09.2008) neovlašćeno umnožavao i radi sticanje imovinske koristi stavljao u promet autorska dela. Celokupan proces umnožavanja i distribucije radio je na adresi svog prebivališta, dok se komunikacija sa klijentima obavljana putem elektronske pošte kreirane korišćenjem poštanskog servisa yahoo. com. U momentu hapšenja od M. S su oduzeta dva računara. Pored računara on je u trenutku hapšenja posedovao i 10.327 komada umnoženih optičkih diskova na

3 Republika Srbija Republičko javno tužilaštvo, „Rad javnih tužilaštava na suzbijanju kriminaliteta i zaštiti ustavnosti i zakonitosti u 2012. godini“.

4 Republika Srbija Republičko javno tužilaštvo, „Rad javnih tužilaštava na suzbijanju kriminaliteta i zaštiti ustavnosti i zakonitosti u 2016. godini“. 
kojima su se nalazila neovlašćeno umnožena autorska dela. Najbrojnija dela bila su u vidu filmova, televizijskih serija, muzike, stripova i drugih multimedijalnih sadržaja [12].

U jednom od procesa okrivljeni je tvrdio da je kolekcionar, i da je zaplenjene filmove sakupljao duži niz godina. Takođe je tvrdio da je pojedine filmove prebacivao sa VHS na DVX radi njihovog lakšeg čuvanja, kao i da je lično pravio omote. Međutim, iako je se branio time da filmovi nisu namenjeni sticanju imovinske koristi istraga je pokazala da je na hard disku računara pronađen veći broj spremljenih omota kao i elektronskih kataloga. Ključni momenat za podizanje optužnice bilo je pronalaženje oglasa u kojima se pored nuđenja usluge presnimavanja nuđena i rasprodaja DVX diskova sa istim naslovima koji su pronađeni kod okrivljenog. Za svaki od naslova bilo je navedeno da količina nije ograničena, takođe bila je navedena cena i broj telefona okrivljenog putem koga mu se zainteresovani kupci mogu obratiti.

\section{ZAKLJUČAK}

Zaštita dobara nastalih kao produkt intelektualnog i kreativnog stvaralaštva čoveka primenom principa intelektualne svojine sa masovnim razvojem cyber prostora postala je izuzetno kompleksna. Kompleksnost se ogleda u velikom broju mogućnosti neovlašćenog korišćenja autorskih dela radi ličnog zadovoljstva ili protiv pravnog sticanja imovinske koristi. U cilju rešavanja ovog problema potrebno je aktivno angažovanje stručnjaka u domenu visokotehnološkog kriminala kao i donošenje adekvatnijih zakonskih regulativa kako na nacionalnom tako i na međunarodnom nivou.

\section{LITERATURA}

[1] D. Popović, "Kritički osvrt na srodnopravnu zaštitu izdavača: zaštita privrednog ili kulturnog poduhvata", Časopis za pravne i društvene nauke, Pravni fakultet Beograd ,Vol. 63, No. 1, 2015

[2] Autorsko i srodna prava, Privredna komora Srbije, dostupno na: http://www.kombeg.org.rs/ aktivnosti/c_privprav/Detaljnije.aspx?veza $=13054$ datum pregleda 05.12.2017.

[3] L. Liang, "Guide to Open Content Licenses", Piet Zwart Institute e for postgraduate studies and research Willem de Kooning Academy Hogeschool Rotterdam, 2005, dostupno na: http://www.theartgalleryofknoxville.com/ocl_v1.2.pdf, datum pregleda: 09.12.2017.
[4] A. M. Laurent, "Understanding Open Source and Free Software Licensing", O'Reilly Media, Inc, 2004. Dostupno na: https://www.safaribooksonline.com/library/view/understanding-opensource/0596005814/, datum pristupa: 09.12.2017

[5] V. Spasic and B. Stevanovic, "Dokazivanje digitalnih povreda prava intelektualne svojine - osvrt na anglosaksonski pravni sistem", u Zbornik radova Pravnog fakulteta u Nišu, Broj 69, 2015, pp. 203 226.,

[6] E. Van der Sar, "Judge Understands BitTorrent, Kills Mass Piracy Lawsuits", dostupno na: https:// torrentfreak.com/judge-understands-bittorrentkills-mass-piracy-lawsuits-140130/, datum pregleda: 06.12.2017.

[7] Enigmax, "The Pirate Bay Trial: Understanding Finreactor", Torrent Freak, dostupno na: https:// torrentfreak.com/the-pirate-bay-trial-understanding-finreactor-090223/, datum pregleda: 05.12.2017.

[8] A. Yoskowitz, "Elite Torrents admin gets 18 months in jail", News by afterdawn, dostupno na: http:// www.afterdawn.com/news/article.cfm/2008/09/10/ elitetorrents_admin_gets_18_months_in_jail, datum pristupa: 05.12.2017.

[9] G. Sandoval, "An interview with alleged KickassTorrents founder in his jail cell in Poland", The Verge, dostupno na https://www.theverge. com/2017/5/23/15681160/kickasstorrents-founderartem-vaulin-interview-bittorrent, datum pristupa: 06.12.2017.

[10] R. McCormick, "Megaupload founder Kim Dotcom can be extradited to the US to face copyright charges", The Verge, dostupno na: https://www.theverge. com/2015/12/22/10655646/megaupload-founderkim-dotcom-can-be-extradited-to-the-us-to-face, datum pregleda: 05.12.2017

[11] S. Gallagher, "The Fast, Fabulous, Allegedly Fraudulent Life of Megaupload's Kim Dotcom“, Wired, dostupno na: https://www.wired.com/2012/01/kimdotcom/, datum pregleda: 07.12.2017

[12] D. Prlja, M. Reljanović and Z. Ivanović, "Internet pravo“, Institut za uporedno pravo Beograd, 2012.

[13] S. Dusollier,"Scoping study on copyright and related rights and the public domain", WIPO, 2010.

[14] A. Diligenski, "Ispitivanje IP-adresa i ugrožavanje privatnosti zbog kršenja autorskih prava gledanjem streaming-a-slučaj Redube", Zaštita podataka o ličnosti, dostupno na: http://partners-serbia.org/ privatnost/blog/ispitivanje-ip-adresa-i-ugrozavanje-privatnosti-zbog-krsenja-autorskih-pravagledanjem-streaming-a-slucaj-redtube/, datum pregleda: 07.12.2017. 